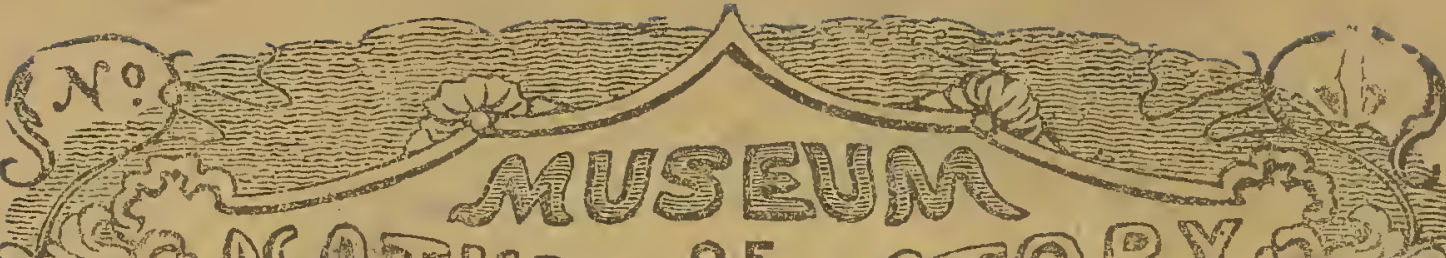

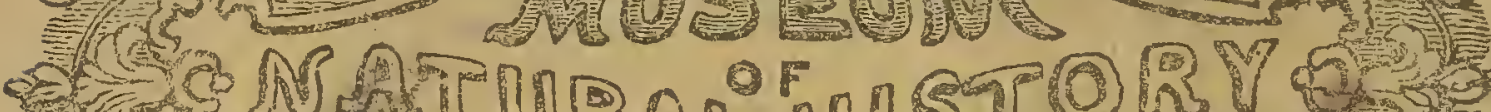

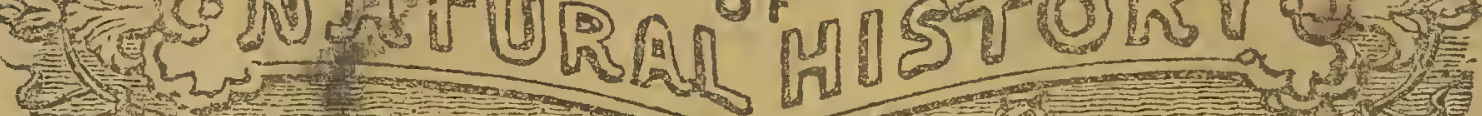

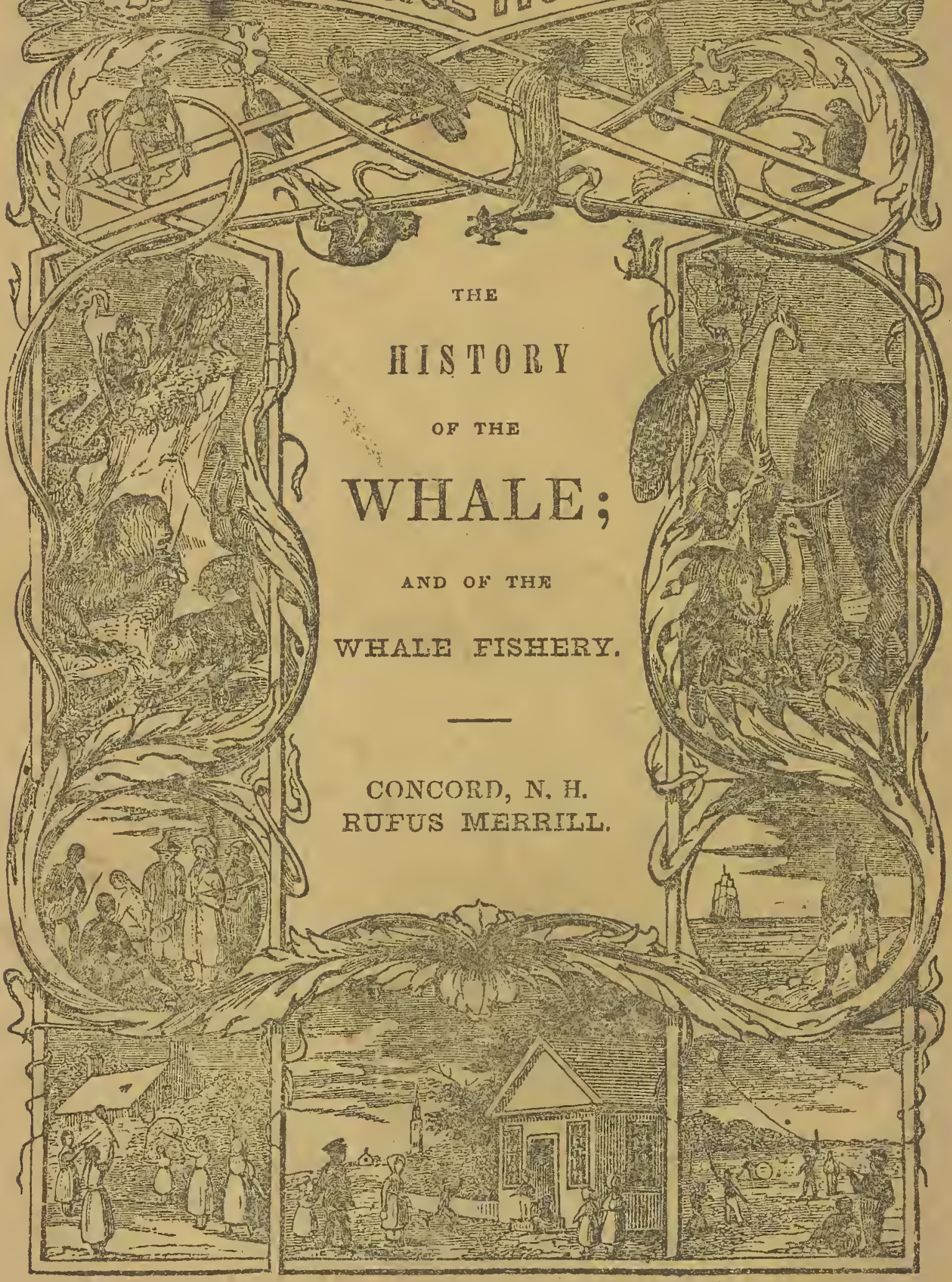




\title{
NATURAL HISTORY
}

\section{OF \\ THE WHALE, \\ WITH AN}

\section{ACCOUNT OF THE WHALE FISHER}

\author{
AND OF
}

THE PERILS ATTLNLING ITS PROSECUTION

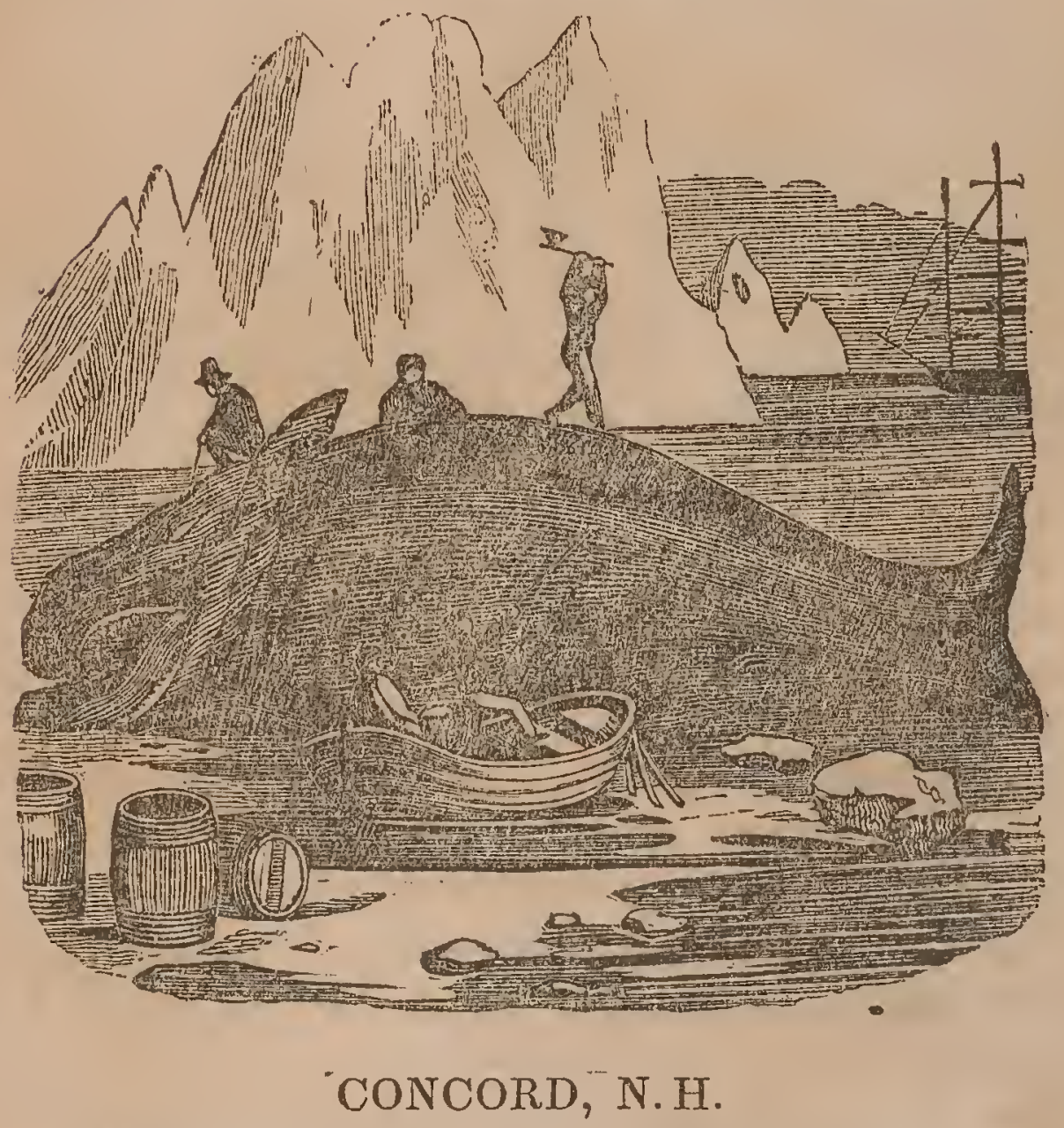

PUBLISHED BY RUFUS MERRILL.

1844. 


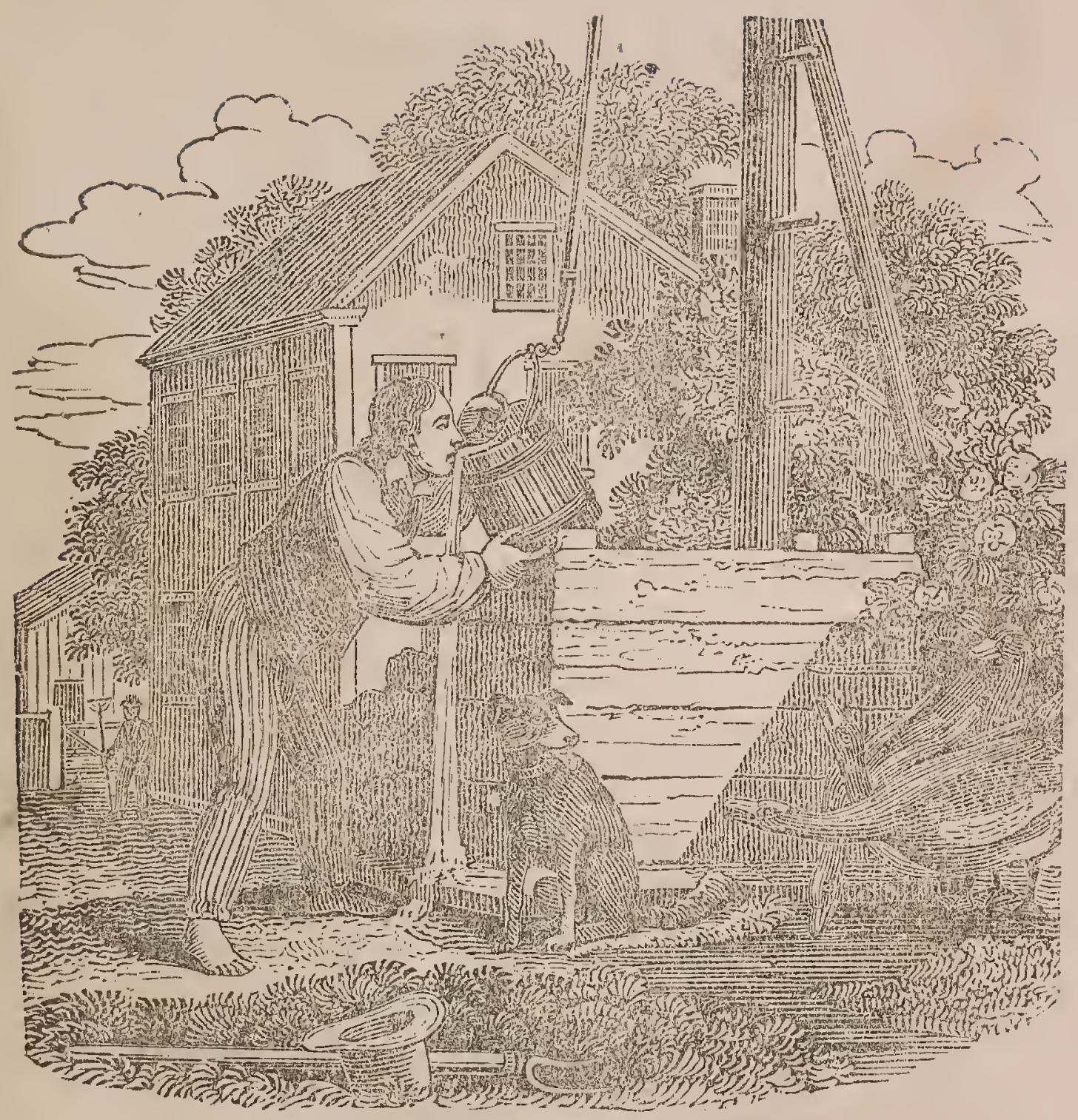

As a variety, we propose in this series to give a page or two of poetry, although the subject may not be applicable to the story. In the present instance, it may be considered to be in p'ace-as we may easily imagine those "fond recollections," so feelingly described in the song of "The old oaken Bucket," to overwhelm those hardy sons of New England while pursuing their long and hazardous journey on the deep; and while deprived of all sight of land for months, their thoughts would naturally revert to the scenes of their childhood and to "the old oaken bucket." - See page 24. 


\section{HISTORY}

\section{$\mathrm{OF}$ \\ THE WHALE.}

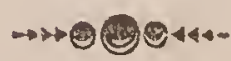

The whale is not only the largest fish, but he is the largest animal in the world. A large whale is twenty times as big as an elephant. According to indications afforded by notches in the whale-bone, which seem not, however, very fully established, the whale does not attain his full growth under twentyfive years, and is supposed to reach a very great age.

The oleaginous substance, or blubber, the most valuable part of the animal, forms a complete wrapper round the whole body, of the thickness of from eight to twenty inches.

The head of the whale is about one third the length of the animal, and the open mouth displays a frightful chasm. The jaw-bones are from sixteen to eighteen inches in length, and extend along the mouth in a curved line, till they meet and form a kind of crescent. The lips, nearly twenty feet long, show, when open, a cavity capable of receiving a ship's jolly-boat, with her crew. The tongue is almost immovably fixed to the lower jaw, seeming one great lump of fat; and, in fact, it fills several hogsheads with blubber. The tail is twenty-four feet broad: 
and when the fish lies on its side, its blow is tremendous; with it he dashes the boats of the whalemen, and disables them, or kills the sailors.

But the most curious feature of the whale is the blow holes, or nostrils, placed nearly on the crown

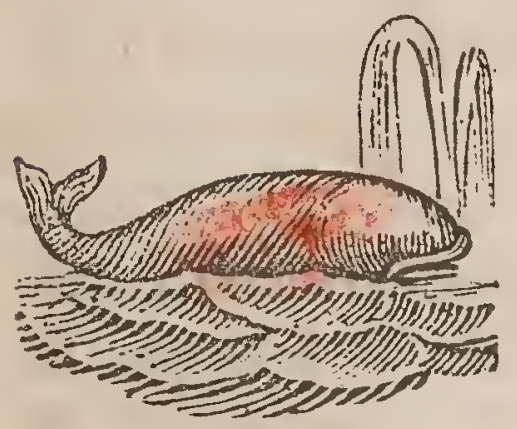
of the head, and which appear like natural jets of water. They emit a warm vapor; and when the breathing is vehement, water is thrown to the height of thirty or forty feet in the air. The sight of this spout, or the loud noise caused by its emission, is the first sign to the whaler of its approach.

The female nourishes its young from her own milk. The mother shows the greatest affection for her young. These delicate nurslings, only 14 or 15 feet in length, and weighing 2000 pounds, are often killed for the sole purpose of provoking an encounter with the parent, and then the contest is deadly and desperate.

The fidelity of these animals to each other exceeds whatever we are told of even the constancy of birds. Some fishers having struck one of two whales, a male and a female, that were in company together, the wounded fish made a long and terrible resistance: it struck down a boat with three men in it, with a single blow of the tail, by which all went to the bottom. 'The other still attended its companion, and lent it every assistance; till, at last, the fish that was struck sunk under the number of its wounds; while its faithful associate, disdaining to survive the loss, with great :

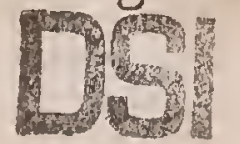


bellowing stretched itself upon the dead fish, and shared its fate.

This inoffensive and lethargic creature sometimes displays vivacity and playfulness. Putting himself in a vertical position, the head downwards, with a rapid motion of the tail he laves the sea into foam and froth. At other times, with a most ludicrous agility, he darts wholly from his element, and the rnass, weighing perhaps seventy tons, is seen suspended in the air. If, as a certain philosopher would make us believe, this earth is only a thin upper-crust, it is happy that he alights on so flexible and elastic a medium as water; for such ungainly pranks might fracture the surface, and give us, however unwillingly, an inspection of the far-famed "Symmes's Hole."

One species, called by the Greenlaniers the razorback, has been known to measure one hundred and five feet in length. This is the largest of the whale tribe. It yields but little oil, and is more violent, restive, and muscular than the other species. He is also swifter, running at the rate of twelve miles an hour; and Mr. Scoresby has seen him, when struck with a harpoon, run off 480 fathoms ( 2880 feet, more than half a mile) of line in a minute.

The common, or right whale, is the exclusive object of the Greenland fishery. The various species of this whale are found in every part of the ocean, but most abundantly in the Greenland seas, and on the banks of Brazil. The valuable products of this animal are common, or right-whale oil, and whalebone. Of 322 individuals of this species, the longest 
was found to be fifty-eight feet in length. Enormous as his bulk is, rumor and the love of the marvellous have represented it as being at one time much great$\mathrm{er}$, and the existing race as only the degenerate remnant of mightier ancestors. A length of sixty feet would imply a weight of seventy tons, or 150,000 pounds, nearly the weight of two hundred fat oxen. Of this vast mass, the oil in a right whale composes about thirty tons; and when, as was the case some years ago, that article brought from $\$ 200$ to $\$ 250$ per ton, we may form some idea of the great value of the capture; the bones of the head, fins, and tail weigh eight or ten; the carcass, thirty or thirty-two tons.

The largest quantity of oil obtained from the right whale, is about 200 barrels. Before the revolutionary war, a sloop from New Bedford captured one in the Straits of Belle Isle, which yielded 212 barrels of oil. Two fish loaded the sloop with 400 barrels of oil, and 100 pounds of bone. 'These, however, were of extraordinary size.

The food of this kind of fish is composed chiefly of small shrimps and animalculæ. We should hardly expect to find, in those cold and dreary regions, much subsistence for the animal creation. But, instead of ceasing, life seems here to spring forth in boundless profusion; the whole Northern ocean teems with minute and almost invisible particles of life. When examined by the microscope, they prove to be of the class vermes, of the genus medusa. They are soft and elastic, and are supposed to tinge the water of an olive-green color for several hundred 
miles. Their number outruns the expression of language; by the estimate of Mr. Scoresby, $80,000 \mathrm{men}$ employed in counting from the creation, could only now have numbered two square miles of these an:malculæ. Amongst these great shoals, the right whale is found. He swims when feeding, with his moutll wide open, occasionally shutting the lower lip, to squecze out the water. The small fish remain entangled in the net-work with which his mouth is furnished, and are devoured.

The sperm whale (blunt-headed cachalot) is of a different genus from the right whale. $\mathrm{He}$ is principally distinguished by a broad blunt head, by a heavy bunch beyond the middle of the back, and by a single blow-hole on the very extremity of the head; while the right whale has two blow-holes, which are placed five or six fret from the nose. It is provided with long arms, on the extremities of which is a kind of sucker's. It is sometimes seen of an immense magnitude.

The spermaceti whales are found in the greatest numbers near the Western Islands, on the coast of Africa, and in the Pacific ocean. While the sperm whale yields far less oil in quantity, it is about three times as valuable as common oil. The spermaceti, called in its crude state, head-matter, is taken from a cavity in the head of the whale, where it is found almost entirely by itself. Some of this kind yield 115 barrels of oil.

While the right whale roams alone, the sperm whale is gregarious, and a herd of two hundred is some- 
times seen. A very unusual and grand appearance of a herd of these whales is thus described by an eye-witness :-

"The ship was becalmed in the Pacific. The man at the rnast head announced as usual, "There she blows!' The boats were manned and lowered as usual. But the whales, instead of rolling heavily along, seemed to approach with great rapidity. 'They appeared to be in an agritation, that could be caused only by agony or fright. They would dart rapidly. Again they would cut in spiral paths, or leap abruptly from their element. Some dashed over the surface, and many of the dark masses, moving like shadows of black clouds, exhibited the same agitation below. All this time, every spiracle gave violent and repeated explosions. We need not say, that the sailors looked on with the silence of death. The herd soon passed beyond the reach of sight, leaving the most experienced to wonder for the unseen and unknown cause of the consternation."

The ships, employed in the whale fishery, are generally from three hundred to three hundred and fifty tons burden. The Greenland ships are buir with all the strength and durability with which wood and iron can be combined, to enable them to withstand the rude concussions of the ice. The ships, according to the necessities of their particular voyage, are manned with from thirty to forty men. The boats are long and narrow, and sharp at each extremity, and are built of the lightest materials for buoyancy and speed. They float upon the surface with the grace 
of the sea-bird upon its peculiar element, and are managed and turned by the steersman and five strong rowers, with amazing dexterity. When cruising, the Greenlanders have the captain or other officer stationed in a little box, called the crow's nest, on the main top. Protected, as far as he can be protected, when the thermometer indicates a temperature ranging from $10^{\circ}$ to $30^{\circ}$ below zero, with his telescope he descries the whale, and guides the ship through the perilous icy channels.

The method of taking the whale is nearly as follows: The whale is compelled to come frequently to the surface, for the purpose of breathing. The nearest boat approaches from behind, from which the harpoon is launched into the huge carcass. This it

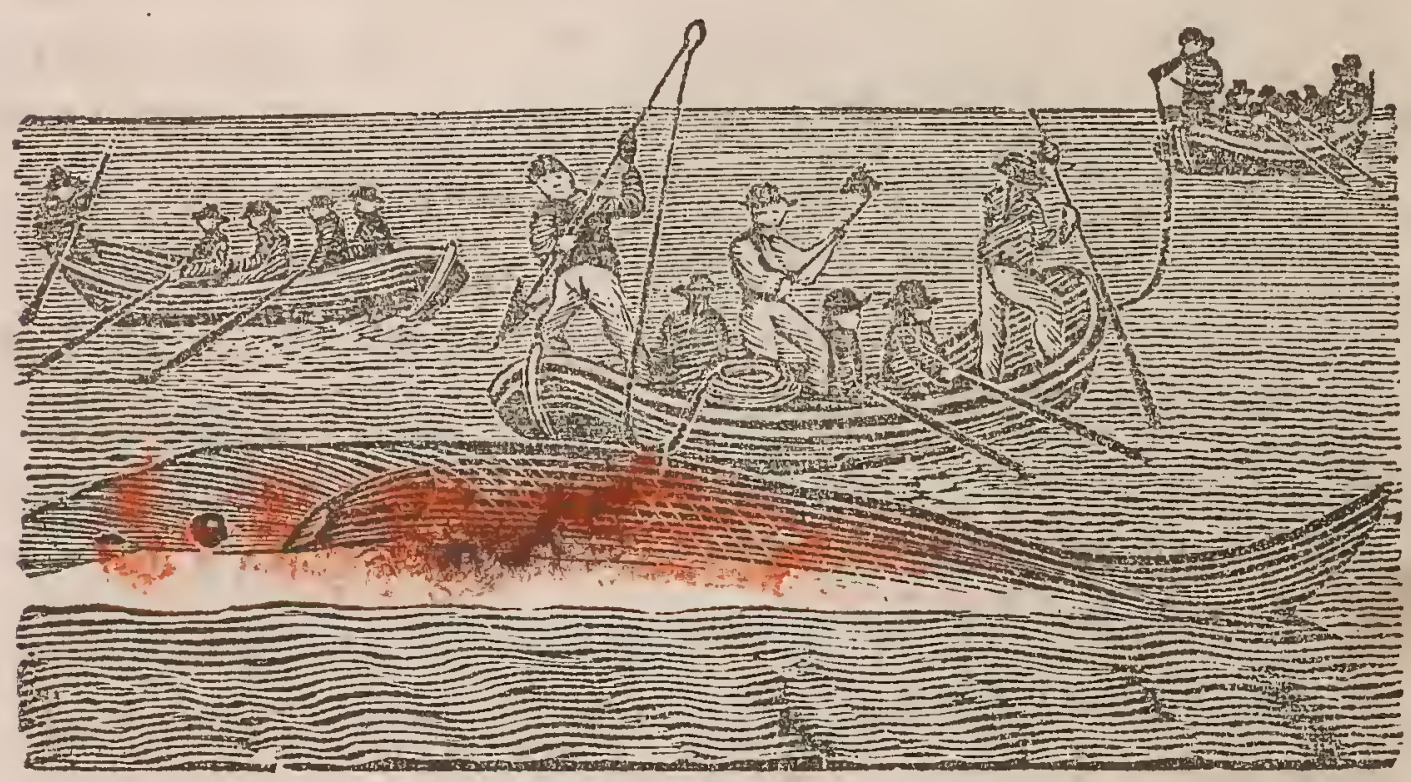

is almost impossible to disengage, it being provided with two strong barbs. If not instantly killed, the whale sinks, and sinks often to a great depth. Exhausted by the superincumbent pressure of the water, he sometimes comes up dead. Frequently he sinks 
only a short distance; but as soon as he rises, the whalemen endeavor to plunge into him the lance, an instrument of the finest steel, sharpened with the keenness of the surgeon's lancet. Attached to the harpoon is a line, which, as the animal is disposed to sink or dash through the waves, is suifered to run loose around a small post in the bow of the boat, and it often flies with such rapidity that the harpooner is enveloped in smoke, and it becomes necessary to pour on water, to prevent the friction from generating flame. They often bind line after line together. If the line becomes entangled while the whale is sinking, the boat rears one end aloft, and makes a majestic dive into the deep. In the contest, sometimes the boat is dashed to shivers, and the men experience no pleasant immersion, if they are fortunate enough to escape without broken limbs. 'The whale, stung with the fatal wound, sometimes dashes along the surface with a death-like energy, and the little boat, almost under water, flies with the velocity of the wind. If he escape, he escapes with a prize on which he has no cause of congratulation, for he carries deeply buried in his body one or more of the sharp instruments, and drags off several hundred fathoms of rope. Our whalemen have found irons in the carcass of a whale, known to have been planted there several years before, on another ocean. As the warp fies, it sometimes throws its coils around the body of a man, and dragging him over, it carries him into the ocean depths, from which he never more emerges. Sometimes it only dislocates or breaks the legs and arms of the 
unfortunate men who become entangled in the folds. A captain of a New London ship was caught by two coils of the warp, one around his body, and another around his leg. He had the presence of mind immediately to seize his knife, and after a while succeeded in cutting himself loose. He was carried, however, to a great depth, and when he returned to the surface, was almost exhausted.

The whale, when roused to desperation, makes an onset with his mouth only. Then he crushes a boat to atoms, and tho men escape by jumping into the sea. A sperm whale destroyed two boats of a Nantucket ship, and then attacked the ship; but being obliged to turn over nearly on his back to use the under jaw, with which he docs execution, the vessel escaped.

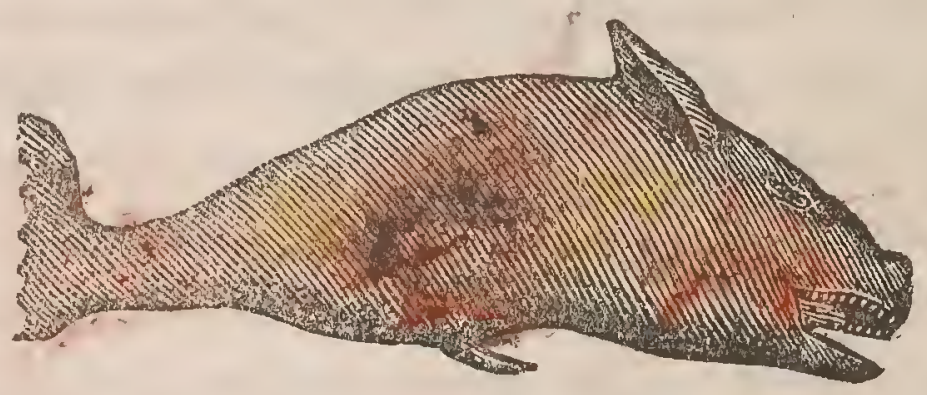

A whale, in attempting to escape, sometimes exerts prodigious strength, and is very dangerous. In 1812, a boat's crew struck a whale near a cake of ice, and very soon made a signal to their companions for more line. While another boat was rowing to their assistance with the utmost speed, the harpooner was seen enveloped in smoke from the friction of the line, which drew the bow of the boat down to a level with the water. When the relief boat was within a hundred yards, the crew were seen to leap into the sea; 
when the boat disappeared beneath the waters, with all the line attached to it. The crew were saved. 'The whale was pursued, and when overtaken, three harpoons were darted at him. The line of two other boats was then run out, which broke, and enabled the whale to carry off, in all, four miles of rope, valued, with the boat, at $\$ 600$. The daring fishers again gave chase, and at last succeeded in capturing him, but not till he had run out 10,440 yards, or about six miles of line.

After the whale is struck with the lance, blood, mixed with oil, streams copiously from his wounds and from the blow-holes, dyeing the sea to a great distance, and sprinkling and sometimes drenching the boats and crews. The animal now becomes more and more exhausted; but, at the approach of his dissolution, he often makes a convulsive and energetic struggle, rearing his tail high in the air, and whirling it with a noise which is heard at the distance of several miles. At length, quite overpowered and exhausted, he lays himself on his back or side, and expires.

The whale, being dead, is lashed alongside the ship. Then, three or four men, with irons on their feet, to prevent them from slipping, get on the whale, and begin to cut out pieces of blubber of about three feet thick, and eight long, which are hoisted into the ship. As soon as they have cleared the whole surface, which does not exceed a fourth or fifth of the animal, the body is turned over, by means of ropes and pulleys, and another part, yet untouched, is presented. This being also cleared, the mass is again 
turned, and so on, till the whole has been exposed, and the blubber removed. The bones of the head being then taken out, the remainder, a huge heap of fleshy and muscular substance, is abandoned, either to sink, or be devoured by the flocks of ravenous birds and sharks, which duly attend on this high occasion. The pieces of blubber are afterwards put into large boilers, and the oil extracted therefrom by boiling.

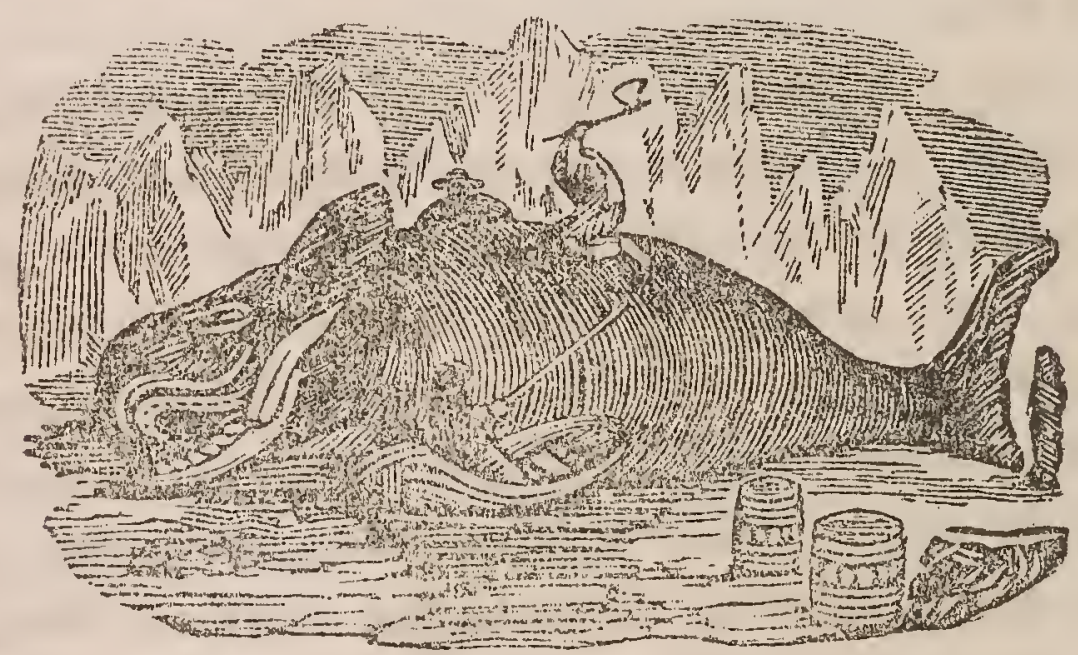

The scraps and pieces of carcass are used for fuel. The oil, when first extracted, is neither nauseous nor rancid, and as a proof of its swectness, the cakes fried in the boilers are considered a great delicacy by the sailors.

The flesh of this animal is a dainty to some nations; and the savages of Greenland, as well as those near the north pole, are fond of it to distraction. They eat the flesh, and drink the oil, which with them is a first-rate delicacy. The finding a dead whale is an adventure considered among the fortunate circumstances of their lives. They make their abode 
beside it, and seldom remove till they have left nothing but the bones.

The products of the sperm fishery are the sperm or lamp oil and spermaceti candles. The products of the right whale are common whale oil and whalebone. After the head-matter of this oil has been compressed, the residue is purified and refined, and then manufactured into those beautiful spermaceti candles, which contribute so much to the brilliancy of our halls and parlors. By a chemical process they can be tinged with any color, and wax-colored candles from Nantucket are often sold for pure wax. There are between fifty and sixty candle manufactories, and the quantity annually made is about $3,000,000$ pounds. The common whale oil is mostly exported to the north of Europe. The whalebone is also mostly exported to Europe: Some of it, howexer, we see deroted to a thousand little purposes at home. We hold it over our heads in the umbrellawe feel it about ou necks in the rigid stock-and the fairer portion of our race can give an account of the consumption of vast quantities more in the marufactures of stays, \&c.

There are about four hundred ships belonging to the United States employed in this fishery, which will average three hundreds tons each. They have generally a crew of twenty-five men each, making an aggregate of 132,000 tons, ard 10,000 men. Taking into the account those employed in carrying the oil, \&c., to market, we find it takes about 840 vessels of various descriptions, measuring 170,000 tons, and 
navigated by 12,000 seamen-about one tenth of the whole navigation of our country. Taking into consideration the manufactories, wharves, stores, and other incidental investments, we shall find that the immense amount of $\$ 70,000,000$ are involved in it, and that more than $\% 0,000$ people derive from it their subsistence. In prosecuting this business there are consumed 45,000 barrels of flour, 36,000 barrels of beef and pork, 900,000 pounds of copper and coppernails, 1,500,000 barrels, 2500 tons of iron hoops, \&c.

Among the accidents that have occurred in the prosecution of this business, the loss of the ship Essex, of Nantucket, is the most remarkable. The following is an abridgment of the narrative of the event, published by the mate of the ship, Mr. Owen Chase.

"I observed a very large whale, as well as I could judge, 85 feet in length. He was lying quietly with his head towards the ship, about twenty rods from the bow. He spouted two or three times, and then disappeared. In less than three seconds he came up again, about the length of the ship off, and made directly for us. I ordered the boy at the helm to shift it, intending to sheer off and avoid him. The words were scarcely out of my mouth before he came down upon us at full speed, and struck the ship with his head on the bow. He gave such an appalling and tremendous jar as nearly threw us all on our faces. The ship brought up as suddenly and violently as if she had struck a rock. We looked at each other in perfect amazement, deprived almost of the power of 
- speech. He passed under the ship, grazing her keel as he went along, came up alongside her to leeward,

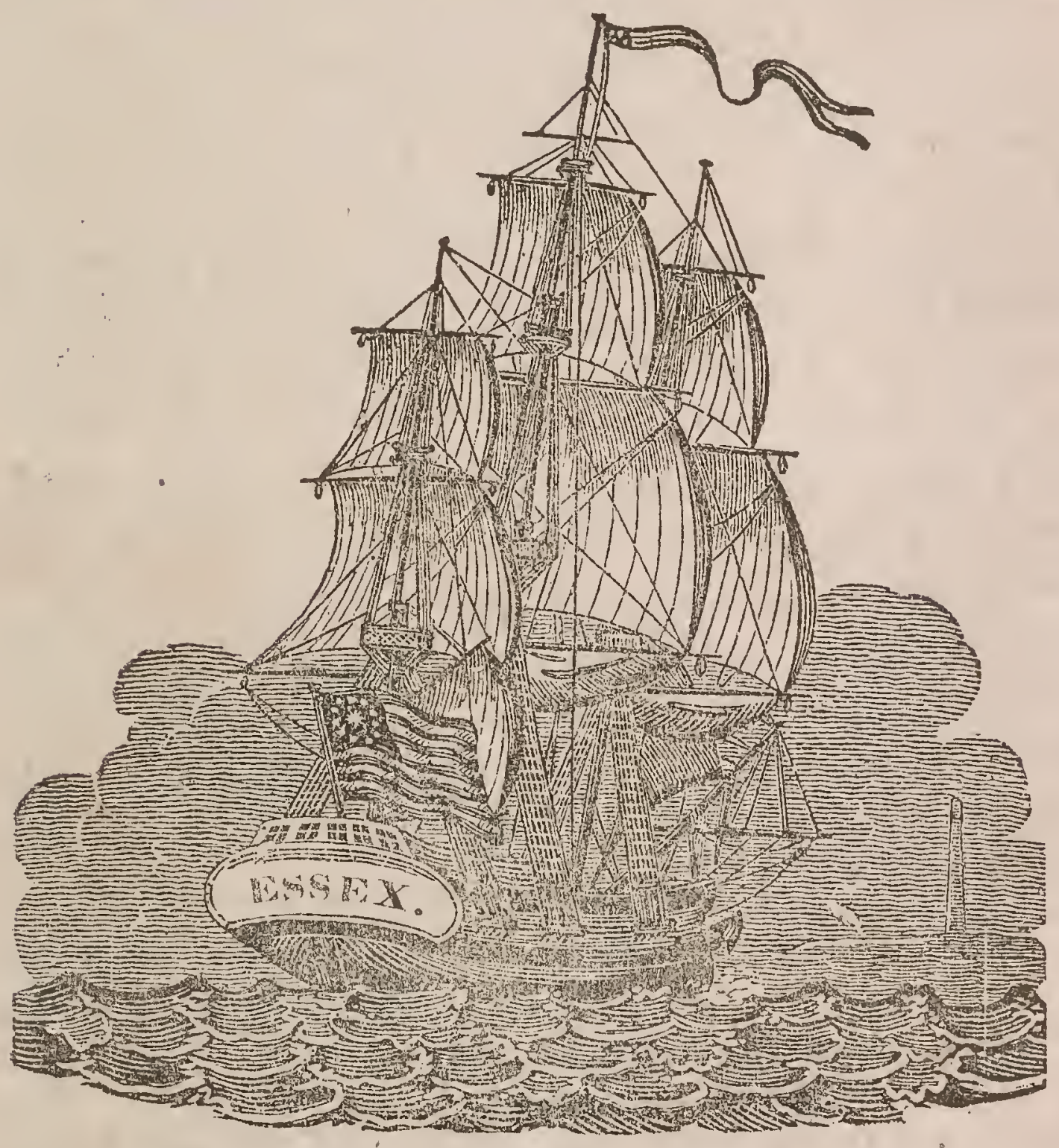

and lay on the top of the water, apparently stunned with the violence of the blow. Supposing he had stove a hole through the ship, I ordered the pumps to be set agoing; but they had not been in operation more than one minute, before $\mathbb{I}$ perceived the head of the ship gradually settling down in the water. I again discovered the whale apparently in convulsions on the top of the water, about 100 rods distant. He 
s enveloped in the foam that his continual and violent threshing about in the water created around him, and I could distinctly see him smite his jaws together, as if distracted with rage and fury. By this time the ship had settled so deep in the water, that I gave her up as lost, and was preparing our boats to escape from the ship, when I was roused by the cry, 'Here he is, -he is making for us again.' I turned round, and saw him about 100 rods directly ahead of us, coming down with apparently twice his ordinary speed, and he appeared to me with tenfold fury and vengeance in his aspect. The surf flew in all directions, and his course towards us was marked by a white foam of a rod in width, which he made by a continual violent threshing of his tail. His head was about half out of water, and in that way he came upon and again struck the ship. I was in hopes, when I descried him making for us, that by putting the ship away immediately, l should be able to cross the line of his approach, before he could get up to us, anc thus avoid what $\mathbb{I}$ knew, if he should strike us again, would be our inevitable destruction. I called out to the helmsman, 'Hard up!' but she had not fallen of more than a point, before we took the second shock. I should judge the speed of the ship, at this time, to have been about three miles an hour, and that of the whale aborit six. He struck her to windward, directly under the cat-head, and completely stove in her bows. He passed under the ship again, went off to leeward, and we saw no more of him." 
This disastrous encounter occurred near the equator, at 1000 miles' distance from land. Provisioned and equipped with whatever they could save from the wreck, twenty men embarked in three slender whale boats, one of which was afterwards croy and leaky. One boat was'never heard of aterwards. The crews of the others sufered every misery that can be conceived, from lamine and exposure. In the captain's boat, they drew lots for the privilege of being shot, to satisfy the rabid hunger of the rest. After nearly three months, the captain's boat, with two survivors, and the mate's boat with three, were taken up at sea, 2000 miles from the scene of the disaster, by different ships.

The source of the most constant alarm to the whale-fisher is connected with the movements of that powerful animal, against which, with most unequal strength, he ventures to contend. Generally, indeed, the whale, notwithstanding his immense strength, is gentle, and even passive; seeking, even when he is most hotly pursued, to escape from his assailants, by plunging into the lowest depths of the ocean. Sometimes, however, he exerts his utmost force in violent and convulsive struggles; and every thing with which, when thus enraged, he comes into collision, is dissipated or destroyed in an instant. The Dutch writers mention Jacques Vienkes, of the Barley Mill, who, after a whale had been struck, was hastening with a second boat to the support of the first. The fish, however, rose, and with its head struck the boat so furiously, that it was shivered to pieces, and Vienkes 
was thrown with its fragments on the back of the huge animal. Even then this bold mariner darted a second harpoon into the body of his victim; but unfortunately he got entangled in the line and could not extricate himself, while the other party was unable to approach near enough to save him. At last, however, the harpoon was disengaged, and he swam to the boat.

Mr. Scoresby, in one of his earliest voyages, saw a boat thrown several yards into the air, from which it fell on its side, plunging the crew into the sea. They were happily taken up, when only one was found to have received a severe contusion. In 1807, Mr. Scoresby's crew had struck a whale, which reappeared in such violent agitation that none dnrst approach it. The captain courageously advanced in a boat by himself, and succeeded in striking a second harpoon; but another boat haring advanced too close, the animal brandished its tail with so much fury, that the harpooner, who was directly under, judged it most prudent to leap into the sea. The tail struck the very place he had left; and cut the boat entirely asunder, with the exception of two planks; so that, had he remained, he must have been dashed "to pieces. Captain Lyons, of Leith, in 1802 , had a boat thrown fifteen feet into the air ; it came down into the water with its keel upwards, yet all the men except one were saved.

The dangers of the northern whale fishery, in spite of the utmost care, and under the direction even of the most experienced mariners, are imminent and 
manifold. The most obvious peril is that of the ship being beset and sometimes dasned to pieces by the approach and collision of those mighty fields and mountains of ice with which those, seas are continually filled.

Didier Albert Raven, a Dutchman, in 1639 , while prosecuting this fishery, was assailed by a furious tempest. There suddenly appeared two immense icebergs, upon which the wind was driving the ressel. 'The ship struck against one so hard, that she was soon found to be sinking. Several boats were launched for escape; but, being overcrowded, they sunk, and all on board perished. Those left in the ship found their condition growing more desperate every moment. The stern separated from the rest of the vessel, carrying with it many of the sailors. The survivors still clung to the wretched fragments; but one after another was washed off, and others, half dead with cold, dropped into the sea, till a crew of eighty-six was reduced to twenty-nine. The sea at last calmed, and they were better enabled to keep their foot-hold on board; but their sufferings from cold, hunger, and burning thirst were so extreme, that death seemed to be a release. The next morning a vessel was seen, and twenty survivors were taken on hoard, after forty-eight hours of extreme danger and suffering.

In 1670, the Bleacher, Captain Pitt, was driven against the ice with such violence, that in an instant all her rigging was dashed in pieces. Soon after, twenty-nine of the crew quitted the vessel, and, leap- 
ing by the help of poles and perches from one fragment of ice to another, contrived to reach the main field. The captain with seven men remained on board, and endeavored to open a passage; but soon after the ship again struck, when the $y$ were obliged to go into a boat, and commit themselves to chance, the snow falling so thick that they could scarcely see each other. As the weather cleared, they discovered their companions on the ice, who threw a whale-line, and dragged them to the same spot. There, the party having waited twelve hours in hopes of relief, at length trusted themselves to the boats, and in a few hours were taken up by a Dutch vessel.

Captain Bille, in 1675, lost a ship richly laden, which went down suddenly; after which the crew wandered in boats over the sea for fourteen days, before they were taken up. Thirteen other vessels perished that year in the Spitzbergen seas. Three seasons afterward, Captain Billc lost a second ship by the violent concussion of the ice, the crew having just time to save themselves on a frozen field.

In 1826, the ship Dundee, of London, had ventured so far to the north that she become completely beset and inclosed within impenetrable barriers, and the crew could obtain no assistance from the other ships. To add to their distress, a Dutch vessel near them was completely wrecked, and the crew, to the number of forty-six, came on board entirely destitute. They were supported from August 23 to October 6 , when they set out in their boats to reach the nearest Danish settlement; but as this was 350 miles distant, 


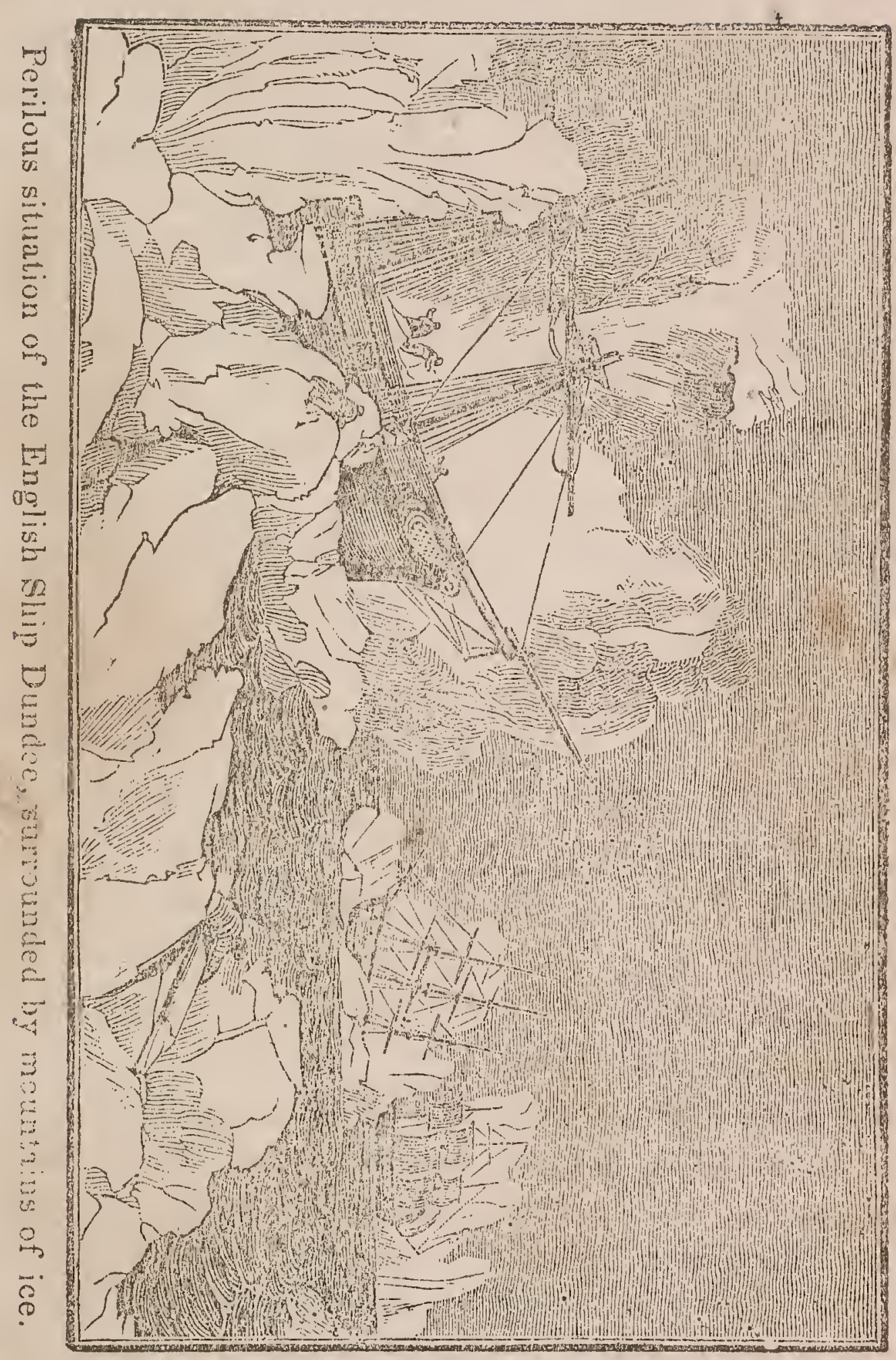

they could have small hope of ever reaching it., The crew of the Dundee were reduced to extreme distress by want of provisions; but the coarse flesh of some seals and bears enabled them to sustain life. On the 
Ist of February they caught a whale, and on the I Gth a second, whicln afiorded great relief. The sea was not sufficiently frozen to prevent cnomous icebergs from tossing about with thundering noise, and teaxing up the fields of ice by which the ship was surrounded. On the $22 \mathrm{~d}$ of February, one of ancommon magnitude was seen bearing dirccily upon their stern, threatening to crush the ship; whercupon the seamen leaped upon the ice, and ran to some distance. The iceberg rolled on with a tremendous crash, breaking the field into a thousand fragnents, and liding the ship from view, which they never expected to sye agrain: but providentially it left her uninjured. 'The mariners lost sight of the sun for seventy-fire days, during which they sufered such severe cold that they could not walk the deck fre mizutes wh hout heing frostbitten. By great good forme, the body of ice in which they were inclosed, drifted to the southward about 800 miles, when the weather became more moderate. On the 1 st of April, they hat the good fortune to mect the ship Ifee, which had just arrived; they were liberally supplied with provisions and every necessary to repair the ship, with which they were enabled to reach home on the $2 \mathrm{~d}$ of June. 


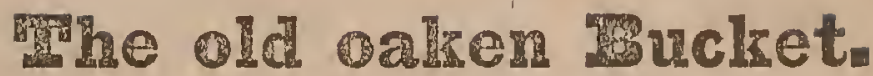

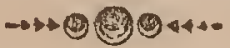

Hcw dear to my heart are the scenes of my childhood,

When fond recollection presents them to view;

The orchard, the meadow, the deep-tangled wild-wood,

And every loved spot which my infancy knew;

The wide-spreading pond, and the mill that stood by it,

The bridge, and the rock where the cataract fell;

The cot of my father, the dairy-house nigh it,

And e'en the rude bucket which hung in the well.

The old oaken bucket-the iron-bound bucket-

The moss-covered bucket which hung in the well.

That moss-covered vessel I hail as a treasure-

For often at noon, when returned from the field,

I found it the source of an exquisite pleasure,

The purest and sweetest that nature can yield.

How ardent I seized it with hands that were glowing,

And quick to the white-pebbled bottom it fell;

Then soon, with the emblem of truth overflowing, .

And dripping with coolness, it rose from the well.

The old oaken bucket-the iron-bound bucket-

The moss-covered bucket arose from the well.

How sweet from the green mossy brim to receive it,

As, poised on the curb, it inclined to my lips!

Not a full, blushing goblet could tempt me to leave it,

Though filled with the nectar that Jupiter sips.

$\Lambda$ nd now, far removed from that loved situation,

The tear of regret will intrusively swell,

As fancy reverts to iny father's plantation,

And sighs for the bucket which hangs in the well.

The old oaken bucket-the iron-bound bucket-

The moss-covered bucket which hangs in the well. 



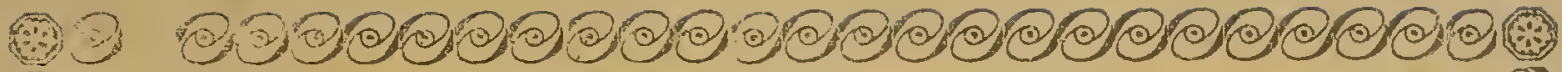

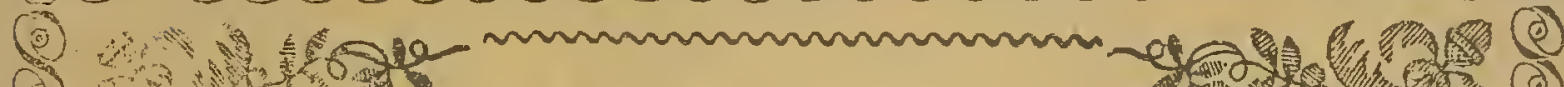

(6)

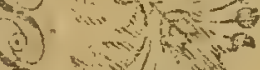

(2) $-x^{2}$

(d)

(3)

(d) 9

(d)

(d)

(2)

(d)

(D)

(d)

(e)

())

d)

b)

(d)

(e)

(e)

(i)

(c)

(d)

(d)

(P)

(e)

(ब)

(d)

(e)

(e)

(2)

(d)

(d)

(D)

(d)

(d)

(e) 2

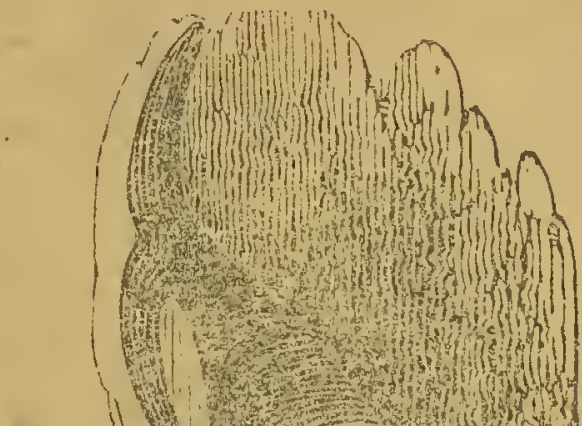

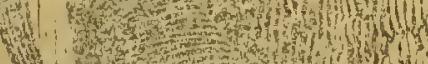

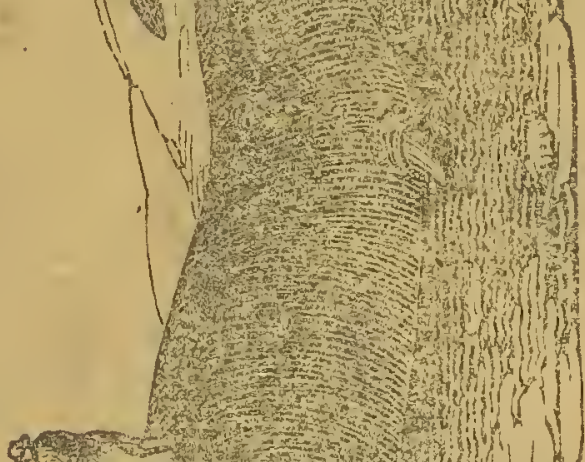

कर

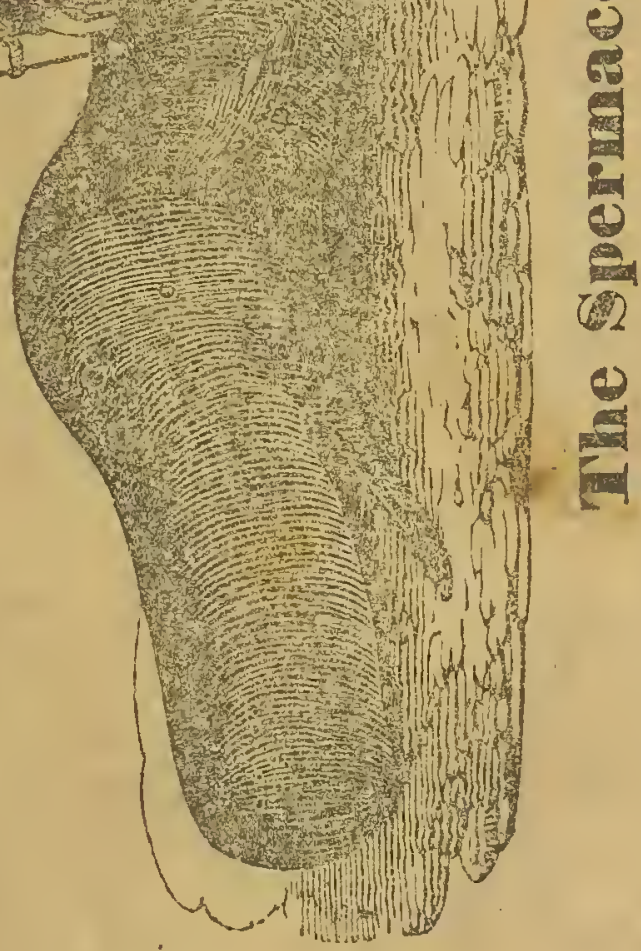

6 -

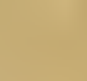

(n)
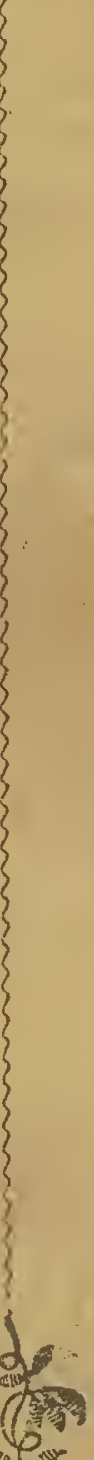

(e) $0^{3}$

(c) 1000

(e) 20

(e)

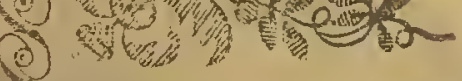

记

.

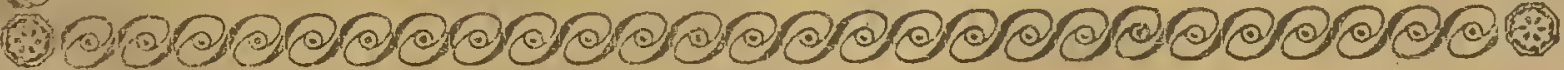

